ROCZNIKI NAUK PRAWNYCH

Tom XXIX, numer 2 - 2019

DOI: http://dx.doi.org/10.18290/rnp.2019.29.2-5

PIOTR SŁAWICKI

\title{
WPEYW USTANOWIENIA ZARZĄDU SUKCESYJNEGO NA POSTĘPOWANIE KLAUZULOWE I EGZEKUCYJNE
}

W dniu 25 listopada 2018 r. w życie weszła ustawa z dnia 5 lipca 2018 r. o zarządzie sukcesyjnym przedsiębiorstwem osoby fizycznej ${ }^{1}$. Wprowadza ona nową instytucję na gruncie prawa polskiego - zarządu sukcesyjnego, którego zadaniem jest tymczasowe zarządzanie przedsiębiorstwem po śmierci przedsiębiorcy będącego osobą fizyczną, a także kontynowanie działalności gospodarczej wykonywanej z wykorzystaniem tego przedsiębiorstwa (art. 1 ZarządSukcU).

Pojęcie zarządu sukcesyjnego - w kontekście brzmienia ustawy - może być odczytywane funkcjonalnie jako instytucja umożliwiająca czasowe funkcjonowanie przedsiębiorstwa po śmierci przedsiębiorcy, jak i przedmiotowo jako ogół praw i obowiązków zarządcy sukcesyjnego, który w okresie przejściowym jest uprawniony i jednocześnie obowiązany do dalszego prowadzenia przedsiębiorstwa ${ }^{2}$. W tym kontekście oceny wymaga status zarządcy sukcesyjnego jako uczestnika ewentualnego postępowania klauzulowego i egzekucyjnego ${ }^{3}$. Nie może bowiem budzić wątpliwość, że śmierć osoby fizycznej ma istotne znaczenie dla biegu określonych postępowań cywilnych i wpływa na decyzje podejmowane przez właściwe organy procesowe.

Dr Piotr SŁAwicki - adiunkt w Katedrze Negocjacji i Mediacji, Instytut Nauk Prawnych, Wydział Prawa, Prawa Kanonicznego i Administracji Katolickiego Uniwersytetu Lubelskiego Jana Pawła II, Al. Racławickie 14, 20-950 Lublin; e-mail: piotr.slawicki@kul.pl; https://orcid. org/0000-0003-4570-9366

${ }^{1}$ Dz. U. poz. 1629 [dalej cyt.: ZarządSukcU].

${ }^{2}$ K. MAJ, Czynności notarialne związane z ustawa o zarzadzie sukcesyjnym przedsiębiorstwem osoby fizycznej, „Krakowski Przegląd Notarialny” 2 (2018), s. 52.

${ }^{3}$ Na potrzeby niniejszego opracowania przyjęto, że postępowanie klauzulowe ma autonomiczny w stosunku do postępowania egzekucyjnego charakter, zob. uzasadnienie uchwały Sądu Najwyższego z dnia 9 listopada 1994 r., sygn. akt III CZP 143/94, „Orzecznictwo Sądu Najwyższego. Izba Cywilna" 1995, nr 3, poz. 46. 
Uzasadnieniem wprowadzenia regulacji było uznanie, że w dotychczasowym stanie prawnym zachowanie pełnej ciągłości działalności przedsiębiorstwa jest w praktyce niemożliwe ${ }^{4}$. Niewątpliwie istotnym argumentem za przyjęciem rozwiązań normatywnych była powszechność jednoosobowego prowadzenia działalności gospodarczej. Ta forma jest bowiem najpopularniejszym sposobem prowadzenia działalności gospodarczej w Polsce, czemu sprzyjają przede wszystkim ograniczone formalności i stosunkowo niskie koszty prowadzenia biznesu' ${ }^{5}$. Do najistotniejszych problemów związanych z kontynuowaniem działalności gospodarczej z wykorzystaniem przedsiębiorstwa zmarłej osoby fizycznej zaliczono między innymi: brak „ośrodka decyzyjnego" - jednej osoby uprawnionej do prowadzenia spraw przedsiębiorstwa i samodzielnej reprezentacji wszystkich następców prawnych; ograniczone możliwości posługiwania się firmą przedsiębiorcy; wygaśnięcie umów o pracę zawartych przez przedsiębiorcę; wygaśnięcie lub brak faktycznej możliwości wykonywania umów cywilnoprawnych związanych z działalnością przedsiębiorstwa; wygaśnięcie decyzji administracyjnych niezbędnych do prowadzenia danego rodzaju działalności gospodarczej, czy ograniczone możliwości przejęcia uprawnień i obowiązków podatkowych ${ }^{6}$.

Celem niniejszego artykułu jest przedstawienie regulacji zarządu sukcesyjnego w odniesieniu do postępowania klauzulowego i egzekucyjnego. Ponadto analizie zostanie poddane zagadnienie aktualności tytułu egzekucyjnego, w którego treści został oznaczony zmarły przedsiębiorca i możliwości wykorzystania go do prowadzenia postępowania egzekucyjnego, pomimo utraty zdolności prawnej przez ten podmiot na skutek jego śmierci. W tym kontekście ocenie poddana zostanie ustawa o zarządzie sukcesyjnym przedsiębiorstwem osoby fizycznej, jak i zmiany dokonane w innych ustawach mających wpływ na toczące się postępowanie egzekucyjne ${ }^{7}$.

${ }^{4}$ Zob. uzasadnienie projektu ustawy o zarządzie sukcesyjnym przedsiębiorstwem osoby fizycznej, Sejm RP VIII Kadencji, Druk nr 2293, s. 6 [dalej cyt.: uzasadnienie].

${ }^{5}$ A. MARIAŃSKI, J. ŻURAWIŃSKI, Sukcesja biznesu a obowiqzujace i projektowane przepisy prawa, $w$ tym $w$ szczególności regulacje klauzuli o przeciwdziałaniu unikaniu opodatkowania, „Monitor Podatkowy" 11 (2017), s. 11.

${ }^{6}$ Zob. uzasadnienie, s. 5-6.

${ }^{7} \mathrm{Na}$ marginesie należy wskazać, że na mocy art. 64 ZarządSukcU znowelizowane zostało postępowanie egzekucyjne w administracji, przy czym zagadnienie to wykracza poza ramy artykułu. 


\section{CEL ZARZĄDU SUKCESYJNEGO}

Zgodnie $\mathrm{z}$ art. 1 ZarządSukcU ustawa reguluje zasady tymczasowego zarządzania przedsiębiorstwem po śmierci przedsiębiorcy ${ }^{8}$, który we własnym imieniu wykonywał działalność gospodarczą na podstawie wpisu do Centralnej Ewidencji i Informacji o Działalności Gospodarczej ${ }^{9}$ oraz kontynuowania działalności gospodarczej wykonywanej z wykorzystaniem tego przedsiębiorstwa. W konsekwencji zasadnie przyjąć należy, że sama instytucja zarządu przedsiębiorstwem po śmierci przedsiębiorcy ma charakter tymczasowy ${ }^{10}$, przy czym obejmuje nie tylko czynności zarządcze w zakresie przedsiębiorstwa zmarłej osoby fizycznej, ale także zmierzające do kontynuowania działalności gospodarczej prowadzonej z wykorzystaniem tego przedsiębiorstwa ${ }^{11}$. Ponadto cechą przyjętych rozwiązań prawnych jest ich dobrowolność, bowiem to od przedsiębiorcy, a po jego śmierci - od jego następców prawnych - zależy, czy skorzystają z możliwości przewidzianych przedmiotową ustawą ${ }^{12}$.

Zasadniczo ustawodawca nie ograniczył zastosowania ustawy do określonego rodzaju działalności gospodarczej ze względu na kryteria związane z jej rodzajem, czy też wielkością. Regulacja jest jednak ograniczona podmiotowo do przedsiębiorców, którzy we własnym imieniu wykonywali działalność gospodarczą na podstawie wpisu do CEIDG. W konsekwencji zasadnicze znaczenie ma ustalenie, czy dany przedsiębiorca na chwilę śmierci był wpisany w przedmiotowej ewiden$\mathrm{cji}^{13}$. Instytucja zarządu sukcesyjnego nie ma zatem zastosowania w sytuacji, gdy wprawdzie wniosek o wpis został złożony, ale do chwili śmierci przedsiębiorca nie został wpisany do CEIDG ${ }^{14}$. Drugą przesłanką jest wykonywanie działalności gospodarczej z wykorzystaniem przedsiębiorstwa ${ }^{15}$. Zasadniczo przedsiębiorstwo

${ }^{8}$ O katalogu praw i obowiązków zarządcy sukcesyjnego w zakresie wykonywania zarządu zob. M. SieradzKa, Zarzad sukcesyjny przedsiębiorstwem osoby fizycznej - analiza i ocena nowych rozwiazań prawnych (cz. II), „Monitor Prawniczy” 23 (2018), s. 1243-1244.

9 Dalej cyt.: CEIDG.

${ }^{10}$ P. BLAJER, Zarząd sukcesyjny przedsiębiorstwem osoby fizycznej. Pytania i odpowiedzi. Wzory pism. Przepisy, Warszawa: Wolters Kluwer Polska Sp. z o.o. 2019, s. 29; J. BieluK, Komentarz do art. 1, [w:] Ustawa o zarzadzie sukcesyjnym przedsiębiorstwem osoby fizycznej. Komentarz, Warszawa: C.H. Beck 2019, Legalis/el.

${ }^{11}$ O kontynuacji stosunków umownych po śmierci przedsiębiorcy zob. SiERADZKA, Zarząd (cz. II), s. 1244-1245; zob. także uzasadnienie, s. 49-54.

12 Zob. uzasadnienie, s. 12.

${ }^{13}$ Zob. tamże, s. 12; przesłanka ta ma charakter formalny, zob. K. KoPACZyŃSKA-PieCZNiAK, Status prawny zarządcy sukcesyjnego, „Przegląd Prawa Handlowego” 12 (2018), s. 4; zob. także Blajer, Zarzą, s. 31.

${ }^{14}$ KopaczyŃSKa-Pieczniak, Status, s. 4.

${ }^{15}$ Przesłanka ta ma charakter materialny, zob. tamże, s. 4-5. 
w spadku powinno być odczytywane zgodnie z definicją z art. $55^{1}$ k.c. ${ }^{16}$, przy czym przyjąć należy, że ustawa częściowo modyfikuje zakres tego pojęcia. Zgodnie bowiem z art. 2 ust. 1 ZarządSukcU przedsiębiorstwo w spadku obejmuje składniki niematerialne i materialne, przeznaczone do wykonywania działalności gospodarczej przez przedsiębiorcę, stanowiące mienie przedsiębiorcy w chwili jego śmierci. Przedsiębiorstwo w spadku obejmuje także składniki niematerialne i materialne, przeznaczone do wykonywania działalności gospodarczej, nabyte przez zarządcę sukcesyjnego albo na podstawie czynności zachowawczych ${ }^{17}$, w okresie od chwili śmierci przedsiębiorcy do dnia wygaśnięcia zarządu sukcesyjnego albo wygaśnięcia uprawnienia do powołania zarządcy sukcesyjnego (art. 2 ust. 3 ZarządSukcU). Nie można zatem wykluczyć sytuacji, w której przedsiębiorstwo w spadku powstanie pomimo faktu, że w majątku zmarłego przedsiębiorcy nie znajdowało się przedsiębiorstwo $\mathrm{w}$ rozumieniu art. $55^{1}$ k.c. ${ }^{18}$

Ustawodawca $\mathrm{w}$ art. 2 ZarządSukcU posługuje się terminem ,przedsiębiorstwo w spadku", a zatem trafnie przyjąć należy, że w przypadku gdy do majątku zmarłego przedsiębiorcy wchodzi kilka przedsiębiorstw w rozumieniu art. $55^{1}$ k.c., wszystkie one będą objęte pojęciem przedsiębiorstwa w spadku w rozumieniu ustawy ${ }^{19}$.

W literaturze wskazuje się, że istotą zarządu sukcesyjnego jest wyodrębnienie składników niematerialnych i materialnych przeznaczonych do wykonywania działalności gospodarczej stanowiących własność przedsiębiorcy w chwili jego śmierci ${ }^{20}$, verba legis - przedsiębiorstwa $\mathrm{w}$ spadku. Celem zaś wyodrębnienia przedsiębiorstwa w spadku jest zapewnienie kontynuowania dotychczasowej działalności, zabezpieczenie prawidłowego funkcjonowania wyodrębnionego mienia i utrzymanie dotychczasowej renomy, przy uwzględnieniu ochrony interesów określonych osób trzecich, np. wierzycieli zmarłego przedsiębiorcy ${ }^{21}$.

${ }^{16}$ Ustawa z dnia 23 kwietnia 1964 r. Kodeks cywilny, Dz. U. Nr 16, poz. 93 z późn. zm. [dalej cyt.: k.c.]; zob. KopaczyŃSKa-PiecZniaK, Status, s. 4-5.

${ }^{17}$ Szerzej o czynnościach zachowawczych zob. M. SIERADZKA, Zarząd sukcesyjny przedsiębiorstwem osoby fizycznej - analiza i ocena nowych rozwiazań prawnych (cz. I), „Monitor Prawniczy” 22 (2018), s. 1196-1198; zob. także uzasadnienie, s. 32-38.

${ }^{18}$ Zob. uzasadnienie, s. 12; SieradZKa, Zarząd (cz. I), s. 1196; M. ZBUCKa, Skutki prawne śmierci przedsiębiorcy, Warszawa: Wolters Kluwer 2018, s. 189; zob. także Bieluk, Komentarz do art. 2 , [w:] Ustawa o zarzadzie sukcesyjnym.

${ }^{19}$ Zob. uzasadnienie, s. 13.

${ }^{20}$ A. Mariański, A. PARDej, Podatkowe konsekwencje zarząu sukcesyjnego, „Przegląd Podatkowy" 6 (2018), s. 26.

${ }^{21}$ KopaCZYŃSKa-PIECZNiak, Status, s. 6; na wzmocnienie ochrony praw osób trzecich zwrócono uwagę także w uzasadnieniu, s. 8. 


\section{STATUS ZARZĄDCY SUKCESYJNEGO}

W tym miejscu analizy wymaga kwestia statusu zarządcy sukcesyjnego. Ma to szczególne znaczenie w toku postępowania klauzulowego i egzekucyjnego, bowiem oceny wymaga, kto będzie stroną czynną i bierną na etapie dochodzenia należności.

Zgodnie z art. 18 ZarządSukcU zarząd sukcesyjny obejmuje zobowiązanie do prowadzenia przedsiębiorstwa $\mathrm{w}$ spadku oraz umocowanie do czynności sądowych i pozasądowych związanych z prowadzeniem przedsiębiorstwa w spadku ${ }^{22}$. Przez prowadzenie przedsiębiorstwa w spadku w ujęciu szerokim należy rozumieć dokonywanie wszelkich czynności, jakie wiążą się z prowadzeniem działalności gospodarczej obejmujące sferę podejmowania decyzji, jak i występowania wobec osób trzecich ${ }^{23}$. Trafnie podnosi się jednak, że na gruncie powołanego przepisu należy przyjąć wąskie rozumienie prowadzenia przedsiębiorstwa w spadku, które obejmuje podejmowanie decyzji dotyczących między innymi spraw organizacyjnych, majątkowych i finansowych, mających na celu zapewnienie jego prawidłowego funkcjonowania ${ }^{24}$. Mogą one przybierać postać czynności faktycznych i prawnych ${ }^{25}$. W ramach prowadzenia przedsiębiorstwa w spadku wykluczone są czynności mające za przedmiot przedsiębiorstwo $\mathrm{w}$ spadku w znaczeniu przedmiotowym, np. zbycie, czy obciążenie przedsiębiorstwa ${ }^{26}$.

Prowadzenie przedsiębiorstwa w spadku nie może być natomiast kwalifikowane jako wykonywanie działalności gospodarczej w rozumieniu ustawy Prawo przedsiębiorców ${ }^{27}$, gdyż zarządca sukcesyjny w specyficzny sposób zastępuje właścicieli przedsiębiorstwa w spadku i nie działa na własny rachunek, zaś skutki jego czynności następują bezpośrednio w majątku właścicieli przedsiębiorstwa w spadku ${ }^{28}$.

Szczególnie istotne znaczenie ma treść art. 21 ust. 1 ZarządSukcU, zgodnie z którym zarządca sukcesyjny działa w imieniu własnym, na rachunek właściciela przedsiębiorstwa w spadku. Należy przyjąć, że przedmiotowa instytucja ma charakter sui generis, gdyż nie odpowiada w pełni żadnej z form przedstawicielstwa ani klasycznemu zastępstwu pośredniemu ${ }^{29}$. Skorelowane jest z tym przyznanie

${ }^{22}$ Trafnie wskazuje się, że kompetencje zarządcy sukcesyjnego regulowane są przepisami bezwzględnie obowiązującymi (wiążącymi), zob. Bieluk, Komentarz do art. 18, [w:] Ustawa o zarządzie sukcesyjnym.

${ }^{23}$ KopaCZyŃSKa-PiecZniak, Status, s. 6.

24 Tamże, s. 8-9.

${ }^{25}$ Zob. uzasadnienie, s. 44-45; Kopaczyńska-Pieczniak, Status, s. 9.

${ }^{26}$ KopacZyŃSKa-PiecZniak, Status, s. 9.

${ }^{27}$ Ustawa z dnia 6 marca 2018 r. Prawo przedsiębiorców, Dz. U. poz. 646 z późn. zm.

${ }^{28}$ Zob. uzasadnienie, s. 18-19.

${ }^{29}$ Zob. tamże, s. 38-40; zob. szerzej KopaczyŃSKa-PiecZniaK, Status, s. 6-8; zob. także SieRADZKA, Zarząd (cz. I), s. 1198. 
zarządcy sukcesyjnemu formalnej legitymacji procesowej, na podstawie której będzie on działał w imieniu własnym, ale na rzecz właścicieli przedsiębiorstwa $\mathrm{w}$ spadku, a zatem to oni pozostaną stroną $\mathrm{w}$ znaczeniu materialnym ${ }^{30}$. Wyrazem normatywnym przedmiotowej legitymacji procesowej jest art. 21 ust. 2 ZarządSukcU, zgodnie z którym zarządca sukcesyjny może pozywać i być pozywany w sprawach wynikających z wykonywanej przez przedsiębiorcę działalności gospodarczej lub prowadzenia przedsiębiorstwa $\mathrm{w}$ spadku oraz brać udział w postępowaniach administracyjnych, podatkowych i sądowoadministracyjnych w tych sprawach. $\mathrm{W}$ postępowaniach $\mathrm{w}$ takich sprawach zarządca sukcesyjny działa $\mathrm{w}$ imieniu własnym, na rzecz właściciela przedsiębiorstwa w spadku. W konsekwencji ustawodawca przyznał zarządcy sukcesyjnemu zdolność sądową i procesową w zakresie postępowań sądowych dotyczących przedsiębiorstwa $\mathrm{w}$ spadku ${ }^{31}$, w tym postępowań klauzulowego i egzekucyjnego.

\section{ZARZĄDCA SUKCESYJNY A INNE INSTYTUCJE ZARZĄDU SPADKIEM}

W pierwszej kolejności należy wskazać, że wprowadzenie zarządu sukcesyjnego do polskiego systemu prawnego nie stoi na przeszkodzie zastosowaniu innych instytucji prawnych przewidzianych dla zarządu spadkiem lub jego zorganizowaną częścią (kurator spadku, wykonawca testamentu) ${ }^{32}$. Zgodnie bowiem z art. 24 ZarządSukcU jeżeli został ustanowiony zarząd sukcesyjny, zarząd spadkiem sprawowany przez kuratora spadku albo wykonawcę testamentu nie obejmuje przedsiębiorstwa w spadku. Wyklucza to kolizję uprawnień w zakresie tego składnika mienia. Dopiero zatem ustanowienie zarządu sukcesyjnego prowadzi do ograniczenia kompetencji kuratora spadku lub wykonawcy testamentu, zaś w przypadku braku powołania zarządcy sukcesyjnego mogą oni podejmować czynności $\mathrm{w}$ zakresie całego majątku, w tym przedsiębiorstwa w spadku. Znajduje to także odzwierciedlenie w art. $667 \S 3$ k.p.c. ${ }^{33}$, zgodnie z którym w przypadku gdy w skład spadku wchodzi przedsiębiorstwo i ustanowiono zarząd sukcesyjny tym

${ }^{30}$ Zob. uzasadnienie, s. 41.

${ }^{31}$ Zob. tamże, s. 68; SiERADZKA, Zarząd (cz. II), s. 1242; zgodnie z uzasadnieniem „ustanowienie zarządu sukcesyjnego wyłącza możliwość samodzielnego zarządzania przedsiębiorstwem w spadku przez jego współwłaścicieli, należy przyjąć, że podobnie jak w przypadku syndyka i zarządcy nieruchomości (art. 935 k.p.c.) podstawienie procesowe ma w tym przypadku charakter bezwzględny", zob. uzasadnienie, s. 41.

${ }^{32}$ Zob. uzasadnienie, s. 42.

${ }^{33}$ Ustawa z dnia 17 listopada 1964 r. Kodeks postępowania cywilnego, Dz. U. Nr 43, poz. 296 z późn. zm. [dalej cyt.: k.p.c.]. 
przedsiębiorstwem, jest ono wyłączone z zarządu majątkiem spadkowym sprawowanego przez kuratora spadku. Przedmiotową regulację należy ocenić pozytywnie, bowiem wyraźnie wyznacza granice zarządu między różnymi podmiotami. Ma to szczególne znaczenie w kontekście regulacji procesowej zawartej w powołanym przepisie z uwagi na to, że kurator spadku jest instytucją powoływaną przez sąd, a zatem ustawodawca trafnie jednoznacznie ustanowił granice zarządu, a tym samym granice sprawowania nadzoru przez sąd spadku (art. $667 \S 2$ k.p.c.).

Prima facie wątpliwości może budzić wyłączenie w art. 24 ZarządSukcU wykonawcy testamentu z zarządu przedsiębiorstwa w spadku. Jest to bowiem instytucja powoływana przez spadkodawcę w testamencie (art. $986 \S 1$ k.c.), a zatem przyjąć można, że stanowi realizację woli testatora, której ustawodawca przypisuje szczególną rolę w kontekście wykładni testamentu ${ }^{34}$. Wydaje się, że o ile przyznanie „wyłączności” zarządu przedsiębiorstwem w spadku na skutek powołania zarządcy sukcesyjnego przez przedsiębiorcę $\mathrm{w}$ trybie art. 9 ZarządSukcU jest jednoznacznie uzasadnione, to pierwszeństwo zarządcy sukcesyjnego powołanego po śmierci przedsiębiorcy na podstawie art. 12 ZarządSukcU może budzić wątpliwości ${ }^{35}$. Projektodawca wskazał, że „nawet jeżeli zarząd sukcesyjny nie został ustanowiony z chwilą śmierci przedsiębiorcy, a sam przedsiębiorca powołał wykonawcę testamentu, należy przyznać osobom uprawnionym możliwość wyłączenia jego umocowania do zarządu mieniem stanowiącym przedsiębiorstwo w spadku przez powołanie zarządcy sukcesyjnego. Trzeba pamiętać, że zarząd sukcesyjny służy realizacji prawa do zarządzania majątkiem właścicieli przedsiębiorstwa w spadku na ich rachunek i z bezpośrednim skutkiem dla nich. Nie byłoby zasadne wyłączenie możliwości skorzystania $\mathrm{z}$ istniejących $\mathrm{w}$ tym zakresie możliwości wynikających z ustawy, np. z trybu przejęcia decyzji związanych z przedsiębiorstwem czy $\mathrm{z}$ utrzymania $\mathrm{w}$ mocy stosunków pracy nawiązanych przez przedsiębiorcę, jedynie z uwagi na fakt, że spadkodawca ustanowił wykonawcę testamentu" ${ }^{\prime 36}$. W konsekwencji pierwszeństwo przyznano interesom następców prawnych, a nie ewentualnej realizacji woli samego przedsiębiorcy. Przyjęte rozwiązania należy ocenić zasadniczo pozytywnie. Cel ustawy jednoznacznie prowadzić ma do umożliwienia kontynuowania działalności gospodarczej po śmierci przedsiębiorcy, a zmierza on nie tylko do zabezpieczenia interesów właścicieli przedsiębiorstwa, ale także osób trzecich, np. pracowników, czy wierzycieli przedsiębiorcy. Biorąc zaś pod uwagę szerszy kontekst społeczny, w szczególności zasadność przygotowania narzędzi

${ }^{34}$ Zob. 948 § 1 k.c.; szerzej o wykładni testamentu zob. M. RzEwuski, Wyktadnia testamentu a okoliczności zewnętrzne towarzyszące testowaniu, „Przegląd Sądowy” 1 (2015), s. 106-119.

${ }^{35}$ Szerzej o powołaniu zarządcy sukcesyjnego zob. D. CELIŃSKI, Czynności notarialne związane z zarzadem sukcesyjnym przedsiębiorstwem osoby fizycznej, „Rejent” 10 (2018), s. 30-40.

${ }^{36}$ Uzasadnienie, s. 42-43. 
prawnych, ułatwiających prowadzenie działalności gospodarczej, jak i zminimalizowanie ryzyk prowadzących do strat $\mathrm{w}$ gospodarce i upadłości przedsiębiorstw, zwiększenie szans na prawidłowe prowadzenie tej działalności w kontekście często zaskakującej śmierci osoby fizycznej będącej przedsiębiorcą stanowi prawidłowy kierunek legislacyjny. W konsekwencji pierwszeństwo w zarządzie przyznane zarządcy sukcesyjnemu przed wykonawcą testamentu, ograniczone do przedsiębiorstwa w spadku, należy ocenić pozytywnie. De lege ferenda rozważenia wymaga, czy kompetencji do powołania zarządcy sukcesyjnego po śmierci przedsiębiorcy nie przyznać dodatkowo wykonawcy testamentu, co umożliwiałoby bezkonfliktowe zarządzanie majątkiem zmarłego, a jednocześnie stanowiłoby niejako domniemaną realizację woli testatora, który powołał wykonawcę testamentu ${ }^{37}$.

Zastanawiać może jedynie dlaczego ustawodawca w art. 635 § 2 k.p.c. rozszerzył katalog podmiotów uprawnionych do złożenia wniosku o zabezpieczenie spadku o zarządcę sukcesyjnego, a jednocześnie nie ujął tej instytucji wśród przesłanek uchylenia przedmiotowego zabezpieczenia z urzędu w przypadku zgłoszenia się tego podmiotu do przejęcia zarządu przedsiębiorstwa w spadku, o którym mowa w art. $636^{1} \S 2$ k.p.c. Wydaje się bowiem zasadne, aby sąd spadku miał możliwość uchylenia zabezpieczenia, chociażby w części dotyczącej tej masy majątkowej.

\section{POWOŁANIE ZARZĄDCY SUKCESYJNEGO A TYTUŁ EGZEKUCYJNY}

Przechodząc do szczegółowych rozważań związanych z wprowadzeniem do systemu prawa polskiego instytucji zarządu sukcesyjnego, należy wskazać, że na skutek zmian normatywnych znowelizowane zostały przepisy kodeksu postępowania cywilnego dotyczące postępowania klauzulowego i egzekucyjnego. W pierwszej kolejności zmianie uległ art. 780 k.p.c., zgodnie z którym jeżeli ustanowiono zarządcę masy majątkowej, kuratora spadku lub zarząd sukcesyjny albo gdy powołano wykonawcę testamentu, do egzekucji z mienia poddanego ich pieczy konieczny jest tytuł egzekucyjny wydany przeciwko zarządcy masy majątkowej, kuratorowi spadku, zarządcy sukcesyjnemu lub wykonawcy testamentu. Przepis $§ 2$ artykułu poprzedzającego stosuje się odpowiednio.

Powyższa zmiana była uzasadniona wprowadzeniem do prawa polskiego nowego rodzaju zarządcy określonej masy majątkowej, a mianowicie przedsiębiorstwa w spadku. W pozostałym zakresie treść normatywna powołanego przepisu pozostała niezmienna, bowiem przedmiotowa norma prawna została jedynie uzupełniona

${ }^{37} \mathrm{Na}$ marginesie należy wskazać, że w doktrynie wskazuje się, że największą słabością regulacji jest brak możliwości powołania zarządcy z urzędu, zob. ZBUCKA, Skutki, s. 211-212. 
o nowy podmiot - zarządcę sukcesyjnego. Przyjęto zatem analogiczne rozwiązania jak w przypadku kuratora spadku, czy też wykonawcy testamentu ${ }^{38}$.

Z treści art. 780 k.p.c. wynika konieczność uzyskania tytułu egzekucyjnego przeciwko zarządcy sukcesyjnemu dla możliwości wszczęcia egzekucji z mienia poddanego pieczy tego zarządcy, a zatem przedsiębiorstwa w spadku ${ }^{39}$. W konsekwencji wierzyciel zmarłego przedsiębiorcy, chcąc dochodzić własnych należności w stosunku do przedsiębiorstwa w spadku na drodze sądowej, powinien wytoczyć powództwo przeciwko zarządcy sukcesyjnemu. Niedopuszczalne jest zaś prowadzenie egzekucji z tej masy majątkowej na podstawie tytułu egzekucyjnego wystawionego przeciwko właścicielowi tej masy ${ }^{40}$. Oczywiste jest, że niedopuszczalne będzie także wszczęcie postępowania rozpoznawczego przeciwko zmarłemu przedsiębiorcy jako stronie stosunku prawnego stanowiącego podstawę powstania wierzytelności, wobec utraty przez ten podmiot zdolności sądowej na skutek śmierci. Z drugiej strony ustawodawca niejako zwolnił z udziału w postępowaniach sądowych właścicieli przedsiębiorstwa w spadku, czyli zasadniczo następców prawnych zmarłego przedsiębiorcy (art. 3 ZarządSukcU).

Na mocy art. $779 \S 2 \mathrm{w}$ zw. z art. 780 k.p.c. w przypadku gdy tytuł egzekucyjny został wydany przeciwko spadkodawcy, przejście obowiązków na spadkobierców następuje stosownie do art. 788 k.p.c. Powołany przepis został - na skutek nowelizacji - zmodyfikowany w podobnym zakresie jak wzmiankowany art. 780 k.p.c., bowiem w art. $788 \S 2$ k.p.c. dodano - do katalogu podmiotów dotychczas w nim zawartym - zarządcę sukcesyjnego. Na jego mocy za przejście uprawnień lub obowiązków, o których mowa w paragrafie poprzedzającym (art. $788 \S 1$ k.p.c. - przyp. P.S.), uważa się również zmiany w prawie rozporządzania mieniem wywołane ustanowieniem zarządcy masy majątkowej, kuratora spadku lub zarządu sukcesyjnego albo powołaniem wykonawcy testamentu, jak również wygaśnięciem funkcji zarządcy masy majątkowej, kuratora spadku, zarządcy sukcesyjnego lub wykonawcy testamentu. Przez ustanowienie zarządu sukcesyjnego należy rozumieć powołanie do tej funkcji zarówno pierwszego, jak i kolejnego zarządcę sukcesyjnego ${ }^{41}$.

W tym miejscu pojawia się pytanie, czy powyższe zmiany nie stanowią superfluum wobec dotychczasowego brzmienia art. 780 i $788 \S 2$ k.p.c. Przedmiotowe

\footnotetext{
${ }^{38}$ Zob. uzasadnienie, s. 70.

${ }^{39} \mathrm{~W}$ doktrynie proponuje się, że w orzeczeniu sądowym strona powinna być oznaczona jako „Zarządca sukcesyjny przedsiębiorstwa w spadku”, w oderwaniu od osoby zarządcy, zob. BiELuK, Komentarz do art. 21, [w:] Ustawa o zarzadzie sukcesyjnym.

${ }^{40}$ Z. SzczureK, Komentarz do art. 780, [w:] Kodeks postępowania cywilnego. Postępowanie zabezpieczajace i egzekucyjne. Komentarz, red. Z. Szczurek, Sopot: Currenda 2017, s. 222.

${ }^{41}$ Zob. uzasadnienie, s. 71.
} 
przepisy obejmowały bowiem zarządcę masy majątkowej, zaś w kontekście definicji przedsiębiorstwa w spadku zawartej w art. 2 ust. 1 ZarządSukcU, zasadne byłoby przyjęcie, że zarządca sukcesyjny jest zarządcą masy majątkowej w rozumieniu dotychczasowych przepisów. Wydaje się jednak, że dla uniknięcia jakichkolwiek wątpliwości w tym zakresie, jak i pewnej konsekwencji w przyjętej aparaturze pojęciowej, zasadnie ustawodawca zmodyfikował te przepisy, co umożliwi ich jednolite stosowanie.

\section{POWOŁANIE ZARZACDCY SUKCESYJNEGO}

\section{A BIEG POSTĘPOWANIA EGZEKUCYJNEGO}

Wprowadzenie instytucji zarządu sukcesyjnego miało wpływ także na zmiany regulacji postępowania egzekucyjnego. Istotnej modyfikacji uległa treść art. 819 k.p.c., który to przepis normował zagadnienie wpływu śmierci uczestnika postępowania egzekucyjnego na dalszy jego bieg. Podstawowa zasada nie uległa zmianie, bowiem organ egzekucyjny jest zobowiązany do obligatoryjnego zawieszenia postępowania egzekucyjnego $\mathrm{z}$ urzędu $\mathrm{w}$ razie śmierci wierzyciela lub dłużnika. Modyfikacji uległ $§ 1 \mathrm{zd}$. 2 powołanego przepisu, zgodnie z którego aktualną treścią postępowanie podejmuje się z udziałem spadkobierców zmarłego albo - w zakresie, w jakim dotyczy ono praw i obowiązków wynikających z działalności gospodarczej - zarządcy sukcesyjnego, jeżeli został ustanowiony zarząd sukcesyjny. W przedmiotowym przepisie dodano możliwość podjęcia postępowania egzekucyjnego z udziałem zarządcy sukcesyjnego w zakresie, w jakim dotyczy ono praw i obowiązków wynikających z działalności gospodarczej, co umożliwi kontynuowanie - po ustanowieniu zarządu sukcesyjnego - egzekucji wszczętej na wniosek albo z majątku przedsiębiorcy ${ }^{42}$. Należy zauważyć, że przedmiotowa regulacja dotyczy zarówno legitymacji czynnej, jak i biernej. W konsekwencji powołanie zarządcy sukcesyjnego umożliwi kontynuowanie postępowania egzekucyjnego w sytuacji, w której zostało ono wszczęte na wniosek zmarłego przedsiębiorcy, jak i wówczas, gdy było ono prowadzone przeciwko temu przedsiębiorcy.

Zasadniczo organ egzekucyjny - jak wskazano wyżej - podejmuje egzekucję w razie ustalenia spadkobierców zmarłego przedsiębiorcy albo ustanowienia zarządu sukcesyjnego. W przypadku jednak gdy spadkobiercy nie objęli spadku albo nie są znani, sąd na wniosek wierzyciela ustanowi dla nich kuratora (art. 819 § 2 k.p.c.). Będzie to możliwe wówczas, gdy nie został wyznaczony kurator spadku. Nawet jednak w takiej sytuacji organ egzekucyjny odmówi ustanowienia kuratora

\footnotetext{
${ }^{42}$ Zob. tamże, s. 71.
} 
w toku postępowania egzekucyjnego, gdy został ustanowiony zarząd sukcesyjny, a egzekucja dotyczy roszczeń wynikających z działalności gospodarczej.

$\mathrm{Z}$ przebiegiem postępowania egzekucyjnego związane jest jeszcze istotne zagadnienie zakresu egzekucji. Zgodnie bowiem z zasadą ogólną tytuł wykonawczy stanowi podstawę do prowadzenia egzekucji o całe objęte nim roszczenie i ze wszystkich części majątku dłużnika, chyba że z treści tytułu wynika co innego (art. 803 w zw. z art. 837 zd. 1 k.p.c.). Ograniczenie odpowiedzialności wynikać powinno zaś z treści tytułu egzekucyjnego (art. 319 k.p.c.) lub też w klauzuli wykonalności powinno być zastrzeżone prawo powoływania się w toku postępowania egzekucyjnego na ograniczoną odpowiedzialność (art. 792 k.p.c.).

Od tej zasady ogólnej wyjątek przewidywał art. 837 zd. 2 k.p.c., który to przepis uległ modyfikacji, dostosowując go do stanu prawnego przewidującego instytucję zarządu sukcesyjnego. Zgodnie z jego znowelizowaną treścią zastrzeżenie (co do ograniczenia odpowiedzialności - przyp. P.S.) nie jest konieczne, jeżeli świadczenie zostało zasądzone od nabywcy majątku, zarządcy ustanowionego przez sąd, kuratora spadku, wykonawcy testamentu lub zarządcy sukcesyjnego z powierzonego im majątku, albo Skarbu Państwa jako spadkobiercy. Przedmiotowy przepis został zatem uzupełniony o sytuację, w której tytuł egzekucyjny obejmuje zasądzenie świadczenia od zarządcy sukcesyjnego ${ }^{43}$.

\section{PODSUMOWANIE}

Powyższe rozważania prowadzą do wniosku, że instytucja zarządcy sukcesyjnego stanowi istotne uzupełnienie prowadzenia jednoosobowej działalności gospodarczej przez osobę fizyczną. Omawiana ustawa reguluje nie tylko charakter zarządu sukcesyjnego i status zarządcy sukcesyjnego, ale także modyfikuje dotychczasowe przepisy, w tym materialne i procesowe. Ma to szczególne znaczenie w kontekście postępowania klauzulowego i egzekucyjnego, bowiem zmiany podmiotowe wpływają niejednokrotnie na praktyczne problemy związane z kontynuowaniem egzekucji. W konsekwencji ustawodawca znowelizował wybrane przepisy obejmujące regulację podstawy egzekucji w zakresie podmiotowych aspektów tytułów egzekucyjnych. Ponadto rozstrzygnął zagadnienie związane z zawieszeniem i podjęciem zawieszonego postępowania egzekucyjnego w przypadku śmierci wierzyciela lub dłużnika będącego osobą fizyczną prowadzącą działalność gospodarczą.

Zasadniczo przedmiotowa regulacja nie budzi wątpliwości, bowiem stanowi ona jedynie uzupełnienie znanych polskiemu prawu instytucji zarządców mieniem

${ }^{43}$ Zob. uzasadnienie, s. 71. 
(np. spadkowym). W konsekwencji interwencja ustawodawcza ograniczona została do wkomponowania instytucji zarządu sukcesyjnego do ram prawnych istniejących dotychczas. W tym zakresie wprowadzone przepisy nie powinny prowadzić do praktycznych problemów w ich stosowaniu.

Kontrowersje może budzić jedynie przyznanie pierwszeństwa zarządowi prowadzonemu przez zarządcę sukcesyjnego w przypadku wyznaczenia przez spadkobiercę wykonawcy testamentu, bez jednoczesnego powołania przez niego zarządcy sukcesyjnego. Wydaje się, że względy celowościowe przemawiają za prawidłowością koncepcji normatywnej przyjętej przez ustawodawcę, jednakże dla realizacji woli testatora, uzasadnione jest uzupełnienie w katalogu osób uprawnionych do powołania zarządcy sukcesyjnego po śmierci przedsiębiorcy - wykonawcy testamentu, jeżeli został on powołany przez zmarłą osobę fizyczną prowadzącą działalność gospodarczą. Podobnie modyfikacji wymaga art. $636^{1} \S 2$ k.p.c. przez uzupełnienie podstaw uchylenia zabezpieczenia spadku.

\section{BIBLIOGRAFIA}

\section{ŹRÓDŁA PRAWA}

Ustawa z dnia 23 kwietnia 1964 r. Kodeks cywilny, Dz. U. z 2019 r., poz. 1145 z późn. zm.

Ustawa z dnia 17 listopada 1964 r. Kodeks postępowania cywilnego, Dz. U. z 2019 r., poz. 1460 z późn. zm.

Ustawa z dnia 6 marca 2018 r. Prawo przedsiębiorców, Dz. U. z 2019 r., poz. 1292 z późn. zm.

Ustawa z dnia 5 lipca 2018 r. o zarządzie sukcesyjnym przedsiębiorstwem osoby fizycznej, Dz. U. poz. 1629 z późn. zm.

\section{ORZECZNICTWO}

Uchwała Sądu Najwyższego z dnia 9 listopada 1994 r., sygn. akt III CZP 143/94, „Orzecznictwo Sądu Najwyższego. Izba Cywilna” 1995, nr 3, poz. 46.

\section{LITERATURA}

BIELUK Jerzy: Ustawa o zarządzie sukcesyjnym przedsiębiorstwem osoby fizycznej. Komentarz, Warszawa: C.H. Beck 2019, Legalis/el.

BLAJER Paweł: Zarząd sukcesyjny przedsiębiorstwem osoby fizycznej. Pytania i odpowiedzi. Wzory pism. Przepisy, Warszawa: Wolters Kluwer Polska Sp. z o.o. 2019.

CELIŃSki Dariusz: Czynności notarialne związane z zarządem sukcesyjnym przedsiębiorstwem osoby fizycznej, Rejent 10 (2018), s. 25-49.

KopaCzyŃSKa-PieCZniaK Katarzyna: Status prawny zarządcy sukcesyjnego, Przeglad Prawa Handlowego 12 (2018), s. 4-11.

MAJ Krzysztof: Czynności notarialne związane z ustawą o zarządzie sukcesyjnym przedsiębiorstwem osoby fizycznej, Krakowski Przegląd Notarialny 2 (2018), s. 51-77.

Mariański Adam, PARdej Anita: Podatkowe konsekwencje zarządu sukcesyjnego, Przegląd Podatkowy 6 (2018), s. 24-29. 
MARIAŃSKI Adam, ŻURAwiŃSKI Jakub: Sukcesja biznesu a obowiązujące i projektowane przepisy prawa, w tym w szczególności regulacje klauzuli o przeciwdziałaniu unikaniu opodatkowania, Monitor Podatkowy 11 (2017), s. 11-15.

RzewUSKi Maciej: Wykładnia testamentu a okoliczności zewnętrzne towarzyszące testowaniu, Przegląd Sądowy 1 (2015), s. 106-119.

SIERADZKa Małgorzata: Zarząd sukcesyjny przedsiębiorstwem osoby fizycznej - analiza i ocena nowych rozwiązań prawnych (cz. I), Monitor Prawniczy 22 (2018), s. 1195-1201.

SieraDzKa Małgorzata: Zarząd sukcesyjny przedsiębiorstwem osoby fizycznej - analiza i ocena nowych rozwiązań prawnych (cz. II), Monitor Prawniczy 23 (2018), s. 1242-1250.

SzczureK Zbigniew: Komentarz do art. 780, [w:] Kodeks postępowania cywilnego. Postępowanie zabezpieczające i egzekucyjne. Komentarz, red. Z. Szczurek, Sopot: Currenda 2017, s. 221-222.

Uzasadnienie projektu ustawy o zarządzie sukcesyjnym przedsiębiorstwem osoby fizycznej, Sejm RP VIII Kadencji, Druk nr 2293.

ZвUCKA Marta: Skutki prawne śmierci przedsiębiorcy, Warszawa: Wolters Kluwer 2018.

\section{WPŁYW USTANOWIENIA ZARZĄDU SUKCESYJNEGO NA POSTĘPOWANIE KLAUZULOWE I EGZEKUCYJNE}

\section{Streszczenie}

Przedmiotem artykułu jest ocena rozwiązań przyjętych w związku z wprowadzeniem do systemu prawa polskiego instytucji zarządu sukcesyjnego w kontekście jej wpływu na postępowanie klauzulowe i egzekucyjne. W pierwszej kolejności przedstawiony zostanie cel zarządu sukcesyjnego oraz status zarządcy sukcesyjnego. W następnej części artykułu instytucja zarządcy sukcesyjnego zostanie poddana analizie porównawczej w stosunku do innych przykładów zarządców masy spadkowej. W końcu, przedstawione zostaną skutki prawne związane z powołaniem zarządcy sukcesyjnego na bieg postępowania egzekucyjnego. Rozważania będą dotyczyły także zakresu legitymacji zarządcy sukcesyjnego do wzięcia udziału w postępowaniu klauzulowym i egzekucyjnym.

Słowa kluczowe: zarząd sukcesyjny; zarządca sukcesyjny; przedsiębiorstwo w spadku

\section{IMPACT OF THE ESTABLISHMENT OF SUCCESSION ADMINISTRATION ON THE ENFORCEMENT-CLAUSE AND ENFORCEMENT PROCEEDINGS}

\section{Sum mary}

The subject of the article is the assessment of solutions adopted in connection with the entry into force of the succession administration institution into the Polish law system in the context of its impact on the clause-enforcement and enforcement proceedings. First, the goal of succession administration and the status of succession administrator will be presented. In the next part of the article, the institution of succession administrator will be subject to a comparative analysis in relation to other examples of succession property administrators. Finally, the legal consequences of establishing a succession administrator for enforcement proceedings will be presented. The considerations will also concern the scope of the succession administrator's legal standing to take part in the clause-enforcement and enforcement proceedings.

Key words: the Succession Administration; the Succession Administrator; the Enterprise in Inheritance 